\title{
PENERAPAN MODEL PEMBELAJARAN KOOPERATIF TIPE NUMBERED HEADS TOGETHER UNTUK MENINGKATKAN AKTIVITAS BELAJAR MATERI POLIMER SISWA KELAS XII IPA SMAN 2 PONTIANAK
}

\author{
Grardus Danggus \\ SMAN 2 Pontianak \\ grardusdanggus@gmail.com
}

\begin{abstract}
This research has been conducted to figure out the improvement of the students learning activities in polymer lesson at twelft grade of science program in SMAN 2 Pontianak by the application of cooperative learning model type numbered heads together. The form of this research is Classroom Action Research. The research was conducted in three cycles. The students learn about the meaning and the reaction how the polymer is formed, the classification of polymer, kinds of plastic, the use and the impact of polymer as well. The instrument used is observation of the students' activities and questioners. Based on the data analysis, it can be concluded that there is improvement on the students learning activities. The percentage of the students activities is $29,03 \%$ in the first cycle, $43,75 \%$ in the second cycle and $84,38 \%$ in the third cycle. It is recommended for the teachers to choose cooperative learning model type numbered heads together to become one of the learning model alternative in polymer lesson to improve the students' learning activities.
\end{abstract}

Keywords : Cooperative learning, numbered heads together.

Pembelajaran kimia di tingkat SMA bertujuan agar siswa dapat memahami konsep, prinsip, hukum, dan teori kimia serta saling keterkaitannya dan penerapannya untuk menyelesaikan masalah dalam kehidupan sehari-hari dan teknologi. Polimer merupakan salah satu materi kimia yang dipelajari di kelas XII IPA semester 6 (genap). Tujuan mempelajari polimer adalah agar siswa dapat menjelaskan pengertian polimer, reaksi pembentukan polimer, mengidentifikasi jenis-jenis polimer, membedakan plastik termoplas dan termoset, menjelaskan sifat polimer, kegunaan polimer, dan dampak negatif penggunaan polimer plastik terhadap lingkungan. (Silabus KTSP kimia SMAN 2 Pontianak).

Polimer adalah molekul yang tersusun atas monomer yang sangat banyak membentuk suatu struktur rantai panjang, dengan bentuk lurus, bercabang, atau saling silang. Berdasarkan reaksi pembentukannya polimer dikelompokan menjadi polimer adisi dan kondensasi sedangkan berdasarkan asalnya dibedakan menjadi polimer alam dan sintesis. Sifat-sifat polimer ditentukan oleh panjangnya rantai, gaya 
antarmolekul, percabangan dan ikatan silang antar rantai polimer. Polimer banyak digunakan dalam kehidupan sehari-hari yaitu untuk bahan berbahan dasar plastik. Plastik tidak dapat diuraikan oleh mikroorganisme, oleh karena itu tidak boleh dibuang langsung ke lingkungan melainkan perlu didaur ulang agar tidak mencemari lingkungan. Sampah plastik sebaiknya tidak dibakar karena asap pembakarannya (terutama plastik PVC) dapat membahayakan kesehatan, karena bersifat karsinogenetik. (Nana Sutresna, 2007).

Selama ini materi polimer dianggap sulit bagi beberapa siswa SMA. Hasil ulangan polimer pada beberapa tahun terakhir di kelas XII IPA SMA Negeri 2 Pontianak tidak memuaskan. Pada semester 6 (genap) tahun 2013 nilai rata-rata ulangan polimer kelas XII IPA adalah 63,02 dengan persentase ketuntasan $48,15 \%$ $(\mathrm{KKM}=75)$. Pembelajaran materi polimer selama ini menggunakan metode ceramah dan diskusi kelas. Hal ini dilakukan karena pada semester genap kegiatan sangat padat, yaitu try out, ujian sekolah pada pertengahan bulan Maret tiap tahunnya sehingga waktu belajar efektif menjadi berkurang. Penerapan metode ceramah dan diskusi kelas ternyata mengakibatkan rendahnya aktivitas siswa dalam belajar, pembelajaran menjadi kurang menarik dan membosankan, sehingga hasil belajar polimer tidak memuaskan (banyak siswa tidak mencapai KKM).

Beberapa hal yang menyebabkan rendahnya aktivitas belajar siswa dalam pembelajaran polimer diantaranya adalah : (1) tidak ada kerjasama antarsiswa dalam belajar ; (2) cenderung belajar sendirisendiri sehingga siswa yang pintar tidak membantu siswa yang kurang pintar ; (3) pemilihan model pembelajaran yang kurang tepat dari guru ; (4) kurangnya sumber belajar yang disediakan oleh guru bagi siswa.

Salah satu cara untuk meningkatkan aktivitas belajar siswa pada pembelajaran materi polimer yaitu dengan menerapkan model pembelajaran kooperatif tipe numbered heads together. Pembelajaran kooperatif dapat mengaktifkan seluruh siswa. Tipe numbered heads together pada dasarnya merupakan jenis diskusi kelompok. Cara ini menjamin keterlibatan total semua siswa. Pembelajaran tipe numbered heads together memberikan kesempatan kepada siswa untuk saling membagikan ide-ide dan mempertimbangkan jawaban yang paling tepat. Selain itu, juga mendorong siswa untuk meningkatkan semangat kerja sama antar siswa.

Model pembelajaran adalah kerangka konseptual yang melukiskan prosedur yang sistematis dalam mengorganisasikan pengalaman belajar untuk mencapai tujuan tertentu. Bruce Joyce dan Marsha Weil (dalam Hendy Hermawan, 2006:3) telah menyajikan berbagai model pembelajaran yang telah dikembangkan dan dites keterpakaiannya oleh pakar pendidikan. Titik berat model pembelajaran adalah pada aktivitas belajar siswa. Jadi hakikat mengajar adalah membantu siswa memperoleh ide, keterampilan, nilai, cara berpikir, sarana untuk mengekspresikan 
dirinya, dan cara-cara belajar bagaimana belajar. Dalam kenyataannya, hasil akhir atau hasil jangka panjang dari proses pembelajaran adalah "the student's increased capabilities to learn more easly and effectively in the future", yaitu siswa meningkatkan kemampuannya untuk dapat belajar lebih mudah dan lebih efektif di masa yang akan datang. Oleh karena itu, proses pembelajaran tidak hanya memiliki makna deskriptif dan keterkinian, akan tetapi juga bermakna prospektif dan berorientasi masa depan.

Menurut Nurhadi dan Senduk (dalam Made Wena, 2009:189) pembelajaran kooperatif adalah pembelajaran yang secara sadar menciptakan interaksi yang silih asah sehingga sumber belajar bagi siswa bukan hanya guru dan buku ajar, tetapi juga sesama siswa. Dalam pembelajaran kooperatif terdapat ciriciri yaitu : adanya tujuan kelompok, akuntabilitas diri, kesempatan yang sama untuk berhasil, kompetisi antar kelompok, adanya spesialisasi tugas, dan adaptasi kebutuhan individu. (Arif Rohman, 2011:186).
Menurut Felder dan Brent (dalam Dasim Budimansyah dkk, 2010:51) pembelajaran bersama mempunyai beberapa karakteristik yaitu : (1) siswa bekerja dalam tim untuk mengerjakan proyek memecahkan masalah ; (2) dapat dilaksanakan dalam jangka waktu yang pendek atau lama. Tujuan pembelajaran kooperatif adalah untuk meningkatkan rasa kebersamaan dan meningkatkan kecerdasan emosional bagi peserta didik.

Roger dan David Johnson (dalam Agus Suprijono, 2013:58) mengatakan bahwa tidak semua belajar kelompok bisa dianggap pembelajaran kooperatif. Untuk mencapai hasil yang lebih maksimal, ada lima unsur dalam model pembelajaran kooperatif yang diterapkan, yaitu : (1) saling ketergantungan positif, (2) tanggung jawab perseorangan, (3) interaksi promotif, (4) komunikasi antar anggota, (5) pemrosesan kelompok. Sintak model pembelajaran kooperatif terdiri dari enam fase, seperti pada Tabel 1 berikut ini.

Tabel 1. Langkah-langkah Pembelajaran Kooperatif.

\begin{tabular}{|l|l|}
\hline \multicolumn{1}{|c|}{ Fase-fase } & \multicolumn{1}{|c|}{ Perilaku Guru } \\
\hline $\begin{array}{l}\text { Fase 1 : Present goals and set. } \\
\text { Menyampaikan tujuan } \\
\text { mempersiapkan peserta didik. }\end{array}$ & $\begin{array}{l}\text { Menjelaskan tujuan pembelajaran dan } \\
\text { mempersiapkan peserta didik siap belajar. }\end{array}$ \\
\hline $\begin{array}{l}\text { Fase 2: Present information. } \\
\text { Menyajikan informasi. }\end{array}$ & $\begin{array}{l}\text { Mempresentasikan informasi kepada peserta } \\
\text { didik secara verbal. }\end{array}$ \\
\hline $\begin{array}{l}\text { Fase 3 : Organize students into } \\
\text { learning teams. }\end{array}$ & $\begin{array}{l}\text { Memberikan penjelasan kepada peserta didik } \\
\text { Mentang tata cara pembentukan tim belajar dan } \\
\text { membanisir peserta didik ke tim-tim belajar. } \\
\text { malam tim kelompok melakukan transisi yang } \\
\text { efisien. }\end{array}$ \\
\hline $\begin{array}{l}\text { Fase 4 : Assist team work and study. } \\
\text { Membantu kerja tim dan belajar. }\end{array}$ & $\begin{array}{l}\text { Membantu tim-tim belajar selama peserta didik } \\
\text { mengerjakan tugasnya. }\end{array}$ \\
\hline Fase 5 : Test on the materials. & Menguji pengetahuan peserta didik mengenai \\
\hline
\end{tabular}




\begin{tabular}{|l|l|}
\hline \multicolumn{1}{|c|}{ Fase-fase } & \multicolumn{1}{c|}{ Perilaku Guru } \\
\hline Mengevaluasi. & $\begin{array}{l}\text { berbagai materi pembelajaran atau kelompok- } \\
\text { kelompok mempresentasikan hasil kerjanya. }\end{array}$ \\
\hline $\begin{array}{l}\text { Fase 6 : Provide recognition. } \\
\text { Memberikan pengakuan atau } \\
\text { penghargaan. }\end{array}$ & $\begin{array}{l}\text { Mempersiapkan cara untuk mengakui usaha dan } \\
\text { prestasi individu maupun kelompok. }\end{array}$ \\
\hline
\end{tabular}

(Sumber, Agus Suprijono, 2013:74).

Tipe belajar numbered heads together (kepala bernomor) dikembangkan oleh Spencer Kagan (1992). Tipe ini memberikan kesempatan kepada siswa untuk saling membagikan ideide dan mempertimbangkan jawaban yang paling tepat. Selain itu tipe ini juga mendorong siswa untuk meningkatkan semangat kerja sama mereka. Tipe ini bisa digunakan dalam semua materi pelajaran, dan juga dapat dilaksanakan pada semua tingkatan usia anak didik.

Numbered heads together adalah suatu tipe belajar dimana setiap siswa diberi nomor kemudian dibuat suatu kelompok lalu secara acak (melalui undian) guru memanggil nomor dari siswa yang menjawab pertanyaan. Pengelompokan siswa sebaiknya dibagi berdasarkan tingkat kecerdasan berdasarkan pengamatan guru pada proses pembelajaran materi sebelumnya. Langkah-langkah pembelajaran tipe numbered heads together : (1) Siswa dibagi dalam kelompok, setiap siswa dalam setiap kelompok mendapat nomor. (2) Guru memberikan tugas dan masingmasing kelompok mengerjakannya. (3) Kelompok mendiskusikan jawaban yang benar dan memastikan tiap anggota kelompok dapat mengerjakannya dan mengetahui jawabannya. (4) Setelah waktu diskusi selesai, guru dibantu siswa melakukan undian nomor soal yang dikerjakan oleh suatu kelompok tertentu. Guru dibantu siswa melakukan undian nomor siswa dalam satu kelompok untuk menentukan siapa yang akan melaporkan hasil kerjasama mereka. (5) Tanggapan dari teman yang lain, kemudian guru menunjuk nomor yang lain. (6) Kesimpulan. (Yatim Rianto, 2010:273).

Tipe numbered heads together memiliki kelebihan dan kekurangan. Kelebihan tipe numbered heads together : (1) setiap siswa menjadi siap ; (2) dapat melakukan diskusi dengan sungguh-sungguh ; (3) siswa yang pandai dapat mengajari siswa yang kurang pandai. Kekurangan tipe numbered heads together : (1) kemungkinan nomor yang sudah dipanggil, dipanggil lagi oleh guru ; (2) tidak semua anggota kelompok dipanggil oleh guru ; (3) dalam pelaksanaannya memerlukan banyak waktu. Dalam tipe ini penugasan dapat diberikan kepada siswa berdasarkan nomornya. Misalnya, siswa nomor 1 bertugas membaca soal dengan benar dan mengumpulkan data yang mungkin berhubungan dengan jawaban soal. Siswa nomor 2, 3, 4, dan 5 bertugas mencari penyelesaian soal. Siswa nomor 6 bertugas mencatat dan melaporkan hasil kerja kelompok jika perlu.

Berdasarkan uraian di atas maka penerapan model pembelajaran 
kooperatif tipe numbered heads together untuk meningkatkan aktivitas belajar siswa pada materi polimer di kelas XII IPA SMA Negeri 2 Pontianak dianggap rasional untuk dilakukan.

Tujuan dari penelitian ini adalah untuk mengetahui peningkatan aktivitas belajar siswa pada materi polimer di kelas XII IPA SMA Negeri 2 Pontianak melalui penerapan model pembelajaran kooperatif tipe numbered heads together. Peneliti juga ingin mengetahui tanggapan siswa kelas XII IPA SMA Negeri 2 Pontianak terhadap penerapan model pembelajaran kooperatif tipe numbered heads together.

\section{Metode}

Bentuk penelitian ini adalah penelitian tindakan kelas (classroom action research). Mulyasa (2010:10) Penelitian Tindakan Kelas (PTK) adalah salah satu penelitian yang dapat dilaksanakan guru sebagai alternatif pilihan untuk menemukan cara dalam rangka meningkatkan mutu atau kualitas pembelajaran di sekolah. Penelitian ini siswa dikenai tindakan yaitu berupa pembelajaran dengan menggunakan model pembelajaran kooperatif tipe numbered heads together.

Paul Suparno (2008:17) menyatakan bahwa tujuan utama penelitian tindakan dalam dunia pendidikan sebagai berikut : (1) untuk melakukan perubahan atau peningkatan yang diteliti secara lebih langsung ; (2) untuk mendekatkan hasil penelitian dengan praktik guru di lapangan sehingga berdasarkan hasil penelitian guru dapat memperbaiki kinerjanya ; mengembangkan profesionalitas para pendidik dalam lingkup kerja.

Aktivitas belajar siswa terhadap pembelajaran kooperatif tipe numbered heads together adalah keikutsertaan siswa secara aktif dalam pembelajaran kooperatif tipe numbered heads together. Ada beberapa jenis aktivitas dalam belajar antara lain : (a) Visual activities, seperti membaca, memperhatikan gambar demonstrasi, percobaan, mengamati pekerjaan orang lain dan sebagainya. (b) Oral activities, seperti menyatakan, merumuskan, bertanya, memberi saran, mengeluarkan pendapat, mengadakan wawancara, diskusi, interupsi, dan sebagainya. (c) Listening activities, seperti mendengarkan uraian, percakapan, diskusi musik, pidato, dan sebagainya. (d) Writing activities, seperti menulis cerita, karangan, laporan, tes, angket, menyalin, dan sebagainya. (e) Drawing activities, seperti menggambar, membuat grafik, peta dan diagram. (f) Motor activities, seperti melakukan percobaan, membuat konstruksi, model mereparasi, bermain, berkebun, memelihara binatang, dan sebagainya. (g) Mental activities, seperti menanggapi, mengingatkan, memecahkan soal, menganalisa, melihat hubungan dan mengambil keputusan. (h) Emotional activities, seperti menaruh minat, merasa bosan, gembira, berani, tenang, gugup, dan sebagainya.

Alat ukur aktivitas belajar siswa berupa lembar observasi aktivitas belajar siswa. Pupuh Fathurrohman dan M. Sorby Sutikno (2010:86) mengartikan observasi sebagai penghimpunan bahan-bahan keterangan yang dilakukan dengan 
mengadakan pengamatan dan pencatatan secara sistematis terhadap berbagai fenomena yang dijadikan objek pengamatan.

Penelitian ini dilaksanakan di SMA Negeri 2 Pontianak, Jalan R. E. Martadinata, Kota Pontianak. Subjek penelitian ini adalah kelas XII IPA 3 yang berjumlah 32 orang, terdiri dari 11 orang laki-laki dan 21 orang perempuan. Pemilihan kelas XII IPA 3 sebagai subjek penelitian karena rata-rata nilai ulangan harian, nilai ujian midsemester dan nilai ujian semester ganjil tahun pelajaran 2013/2014 lebih rendah daripada kelas XII IPA 1 dan kelas XII IPA 2.

Instrumen yang digunakan dalam penelitian ini adalah : (1) Lembar observasi aktivitas belajar siswa. Lembar observasi aktivitas siswa pada penelitian ini digunakan untuk mengamati aktivitas siswa pada proses pembelajaran kooperatif tipe numbered heads together. Indikator aktivitas yang diamati untuk dijadikan bahan analisis adalah aktivitas pada saat pelaksanaan presentasi hasil diskusi, yaitu mengajukan pertanyaan jika belum mengerti, menjawab pertanyaan dan menanggapi presentasi teman. (2) Lembar kuesioner tanggapan siswa. Lembar kuesioner ini digunakan untuk mengetahui bagaimana tanggapan siswa terhadap penerapan model pembelajaran kooperatif tipe numbered heads together yang dilakukan pada materi polimer untuk meningkatkan hasil belajar siswa. Selanjutnya hasil tanggapan dari siswa dianalisis untuk dibuat kesimpulan. Penelitian terdiri dari 3 siklus dengan alur kegiatan seperti pada Gambar 1 berikut ini.

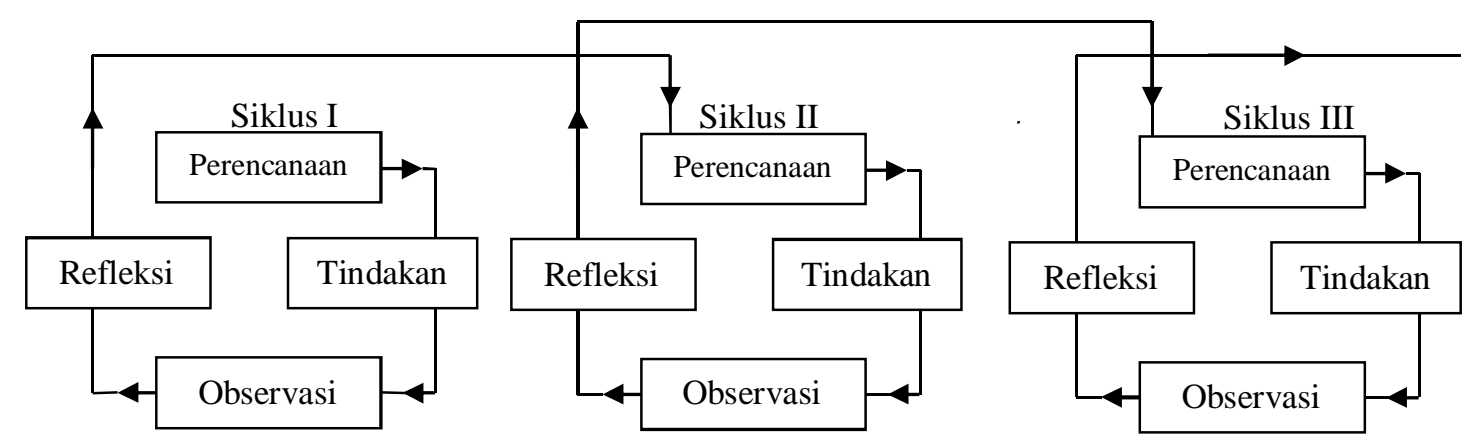

Gambar 1. Kajian Berdaur 4 Tahap Penelitian Tindakan Kelas (PTK).

Penjelasan secara rinci dari 3 siklus pada gambar di atas sebagai berikut:

1. Siklus I

Perencanaan Tindakan.

Kegiatan yang dilakukan adalah menyusun instrumen pembelajaran, yaitu menulis silabus, analisis standar kompetensi dan kompetensi dasar, lembar kerja polimer, rencana pelaksanaan pembelajaran, menulis kisi-kisi dan soal diskusi dan post test, lembar observasi kegiatan guru selama proses pembelajaran dan menulis lembar hasil pengamatan aktivitas belajar siswa.

Pelaksanaan Tindakan. Pada tahap ini guru melaksanakan proses pembelajaran siklus I sesuai dengan 
rencana yang telah disusun sebelumnya.

Observasi

Tindakan.

Observasi dilakukan dan dibantu oleh dua orang guru kimia SMAN 2 Pontianak.

Refleksi Tindakan. Setelah pelaksanaan tindakan dilakukan maka peneliti bersama observer mendiskusikan : (a) Kekurangankekurangan yang ditemukan pada pelaksanaan tindakan siklus I. (b) Menghitung persentase keaktifan belajar siswa siklus I. Refleksi dilakukan untuk menemukan solusi yang harus dilakukan untuk mengatasi kekurangan-kekurangan yang ditemukan pada proses pembelajaran siklus I untuk diperbaiki pada pelaksanaan pembelajaran siklus selanjutnya.

2. Siklus II

Pada siklus II, kegiatankegiatan yang dilakukan bertujuan untuk memperbaiki pelaksanaan pembelajaran pada siklus I. Kegiatankegiatan pada siklus II sama dengan siklus I yaitu perencanaan tindakan, pelaksanaan tindakan, observasi dan refleksi.

\section{Siklus III}

Penelitian ini direncanakan dilakukan dalam tiga siklus. Siklus III dilakukan apabila hasil aktivitas belajar siswa pada siklus II belum mencapai indikator yang telah ditetapkan. Kegiatan-kegiatan pada siklus III sama dengan siklus II yaitu perencanaan tindakan, pelaksanaan tindakan, observasi dan refleksi.

4. Kegiatan Akhir

Kegiatan akhir dari penelitian ini adalah : (1) Menulis angket (kuesioner) pendapat siswa. (2) Mengisi angket, menganalisa data dan membuat analisis hasil angket pelaksanaan model pembelajaran kooperatif tipe numbered heads together. (3) Menulis hasil dan pembahasan hasil penelitian. (4) Mengadakan seminar hasil penelitian. (5) Menulis laporan penelitian.

Teknik pengumpulan data pada penelitian ini adalah dengan teknik observasi langsung. Data observasi yang dikumpulkan pada penelitian ini adalah aktivitas siswa saat presentasi hasil diskusi berlangsung yaitu mencatat siswa yang mengajukan pertanyaan dan menjawab pertanyaan. Lembar observasi yang digunakan ada dua yaitu : (1) hasil pengamatan aktivitas belajar siswa ; (2) hasil pengamatan aktivitas guru. Peneliti juga ingin mengetahui tanggapan siswa terhadap pelaksanaan model pembelajaran kooperatif tipe numbered heads together menggunakan lembar kuesioner.

Untuk mengukur keberhasilan pembelajaran pada penelitian ini diperlukan indikator. Indikatornya adalah minimal keaktifan belajar $60 \%$ dari jumlah siswa yang mengikuti proses pembelajaran.

\section{Hasil dan Pembahasan}

A. Siklus I

Hasil pengamatan aktivitas belajar siswa pada siklus I dapat dilihat pada Tabel 2 berikut ini.

Tabel 2. Hasil Pengamatan Aktivitas Belajar Siswa Siklus I.

\begin{tabular}{lc}
\hline No Indikator & $\begin{array}{c}\text { Jumlah } \\
\text { Siswa }\end{array}$ \\
\hline 1. Mengajukan pertanyaan & 4 \\
2. Menjawab pertanyaan & 5 \\
Jumlah siswa melakukan & 9 \\
aktivitas & 31 \\
Jumlah siswa & $29,03 \%$ \\
Persentase keaktifan & \\
\hline
\end{tabular}


Observasi
tindakan. Hasil observasi sebagai
berikut : (1) Guru belum mengatur
waktu belajar dengan baik dimana
terlalu lama memberikan penjelasan
pada kegiatan awal pelajaran dan
waktu presentasi. (2) Guru belum
membimbing siswa dengan baik
dimana guru lebih banyak membimbing kelompok siswa yang dekat dengan papan tulis sedangkan kelompok yang ditengah dan dibelakang kurang diberikan bimbingan. (3) Guru masih mendominasi dan kurang sabar saat presentasi dimana jawaban pertanyaan diskusi yang terlalu lama dijawab oleh siswa terlalu cepat dijawab oleh guru. (4) Diskusi kelompok belum berjalan dengan baik dimana terlihat beberapa siswa pasif/kurang berpartisipasi dalam diskusi. (5) Teknik bertanya siswa masih kurang dimana beberapa pertanyaan siswa menyimpang dari materi diskusi. (6) Penguasaan materi siswa yang mempresentasikan jawaban hasil diskusi masih kurang dimana sewaktu diberikan pertanyaan oleh temannya terlalu lama memikirkan jawabannya. Refleksi pelaksanaan tindakan siklus I dilakukan untuk memperbaiki kekurangan-kekurangan yang ditemukan saat pelaksanaan pembelajaran. Beberapa solusi untuk diterapkan pada pelaksanaan tindakan II adalah : (1) guru harus mengalokasikan waktu presentasi sesuai yang tercantum dalam RPP ; (2) guru lebih memotivasi dan mendorong siswa untuk dapat bekerja sama ; (3) guru lebih dapat memancing siswa untuk berani bertanya dan menjawab pertanyaan ;
(4) guru menegaskan agar siswa bertanya sesuai dengan materi yang dibahas ; (5) diberikan batas waktu untuk menjawab pertanyaan, apabila waktu telah lewat maka jawaban dilemparkan kepada siswa yang telah siap menjawab ; (6) guru menegaskan agar menjawab pertanyaan jangan langsung membaca dari buku atau lembar kerja, baca buku atau lembar kerja di rumah.

B. Siklus II

Hasil pengamatan aktivitas belajar siswa pada siklus II dapat dilihat pada Tabel 3 berikut ini.

Tabel 3. Hasil Pengamatan Aktivitas Belajar Siswa Siklus II.

\begin{tabular}{lc}
\hline No $\quad$ Indikator & $\begin{array}{c}\text { Jumlah } \\
\text { Siswa }\end{array}$ \\
\hline 1. Mengajukan pertanyaan & 9 \\
2. Menjawab pertanyaan & 5 \\
Jumlah siswa melakukan & 14 \\
aktivitas & 32 \\
Jumlah siswa & \\
Persentase keaktifan & $43,75 \%$ \\
\hline
\end{tabular}

Hasil observasi pelaksanaan tindakan siklus II sebagai berikut : (1) Pengaturan waktu belajar sudah baik dimana pelaksanaan pembelajaran hampir sesuai dengan waktu yang dialokasikan dalam RPP. (2) Guru masih kurang dalam mengaktifkan siswa dimana siswa yang bertanya dan menjawab pertanyaan saat pelaksanaan presentasi masih kurang dan masih didominasi oleh siswa tertentu saja. (3) Siswa yang menjawab pertanyaan tidak harus yang maju presentasi, bisa dibantu teman dalam satu kelompok agar semua aktif. (4) Masih ada siswa yang kurang siap sehingga saat presentasi terlalu lama berfikir untuk menjawab pertanyaan temannya. (5) 
Masih ada pertanyaan siswa yang menyimpang dari materi diskusi.

Refleksi pelaksanaan tindakan siklus II. Beberapa solusi untuk memperbaiki kekurangan yang ditemukan pada siklus II untuk diterapkan pada pelaksanaan tindakan III adalah : (1) memberikan motivasi lebih terutama bagi siswa yang kelihatannya kurang aktif dalam diskusi ; (2) memberikan nilai tambah bagi siswa yang menjawab pertanyaan temannya ; (3) menegaskan batas waktu untuk berfikir menjawab pertanyaan temannya, jika belum siap maka guru memberikan kesempatan kepada siswa lain yang sudah siap untuk menjawab ; (4) mengutamakan siswa yang bertanya atau menjawab pertanyaan adalah siswa yang belum mendapat kesempatan pada siklus I dan siklus II.

\section{Siklus III}

Hasil pengamatan aktivitas belajar siswa pada siklus III dapat dilihat pada Tabel 4 berikut ini.

Tabel 4. Hasil Pengamatan Aktivitas Belajar Siswa Siklus III.

\begin{tabular}{lc}
\hline No Indikator & $\begin{array}{c}\text { Jumlah } \\
\text { Siswa }\end{array}$ \\
\hline 1. Mengajukan pertanyaan & 13 \\
2. Menjawab pertanyaan & 10 \\
Jumlah siswa melakukan & 23 \\
aktivitas & 32 \\
Jumlah siswa & $71,88 \%$ \\
Persentase keaktifan & \\
\hline
\end{tabular}

Persentase keaktifan belajar siklus III telah melampui indikator keberhasilan yang ditetapkan pada penelitian ini yaitu minimal keaktifan belajar $60 \%$ dari jumlah siswa yang mengikuti proses pembelajaran.

Hasil observasi tindakan siklus III sebagai berikut : (1) Pelaksanaan pembelajaran sangat baik dan lancar, dimana siswa sangat aktif. (2) Interaksi antarsiswa sangat baik dibanding dengan siklus I dan II dimana siswa terlihat tidak canggung lagi dalam berdiskusi. (3) Keaktifan siswa dalam bertanya serta menjawab pertanyaan meningkat dimana semakin banyak siswa yang memberanikan diri untuk bertanya dan menjawab presentasi yang disampaikan teman di depan kelas. (4) Siswa lebih siap untuk berfikir dari siklus sebelumnya dimana siswa cepat menjawab pertanyaan temannya pada saat presentasi.

Peningkatan aktivitas belajar dapat diketahui dari semakin banyaknya jumlah siswa yang aktif dalam proses pembelajaran. Jika dibandingkan dengan siklus I, pada siklus II aktivitas siswa mengalami peningkatan yakni dari 29,03\% menjadi $43,75 \%$, dan jika dibandingkan dengan siklus II, pada siklus III aktivitas belajar siswa mengalami peningkatan dari $43,75 \%$ menjadi $71,88 \%$. Peningkatan aktivitas belajar dapat dilihat pada Tabel 5 berikut ini.

Tabel 5. Peningkatan Aktivitas Belajar Siswa Setiap Siklus.

\begin{tabular}{ccccc}
\hline No & Siklus & Jumlah Siswa & Jumlah Siswa Aktif & Persentase Keaktifan \\
\hline 1 & I & 31 & 9 & $29,03 \%$ \\
2 & II & 32 & 14 & $43,75 \%$ \\
3 & III & 32 & 23 & $71,88 \%$ \\
\hline
\end{tabular}


$\begin{array}{llr}\quad \text { Hasil } & \text { tanggapan } & \text { siswa } \\ \text { terhadap } & \text { penerapan } & \text { model } \\ \text { pembelajaran } & \text { kooperatif } & \text { tipe }\end{array}$ pembelajaran kooperatif tipe mumbered heads together dapat dijelaskan sebagai berikut : semua siswa senang untuk belajar, dapat membantu siswa untuk meningkatkan kerjasama dalam diskusi, dapat meningkatkan hasil belajar, tidak banyak menemukan kesulitan bagi siswa, dapat meningkatkan kepercayaan diri siswa dalam memecahkan masalah kimia, dapat meningkatkan kepercayaan diri mereka untuk memberanikan diri mempresentasikan jawaban dihadapan teman-teman di depan kelas dan siswa setuju mengenai sedikitnya waktu penjelasan guru pada model pembelajaran kooperatif tipe numbered heads together.

Hubungan hasil penelitian dengan teori belajar konstruktivisme sosial. Teori konstruktivisme sosial Vigotsky (dalam Agus Suprijono, 2013:55) menekankan bahwa pengetahuan dibangun dan dikonstruksi secara mutual. Pembelajaran konstruktivisme dapat berjalan efektif jika peserta didik telah mempunyai prior knowledge (pengetahuan awal). Untuk itu seminggu sebelum pelaksanaan tindakan, guru membagikan LKS polimer untuk dipelajari siswa di rumah. Pada pelaksanaan tindakan I sampai III, terlihat bahwa pelaksanaan diskusi berjalan baik dimana mereka dapat membagi ideide untuk menjawab soal diskusi, bertanya jawab antara anggota didalam kelompoknya. Jadi setiap kelompok diskusi dapat membangun pengetahuan secara bersama untuk mendapatkan jawaban yang benar dari setiap soal diskusi. Jadi, membangun pengetahuan secara bersama dan membagi ide-ide secara sukarela diantara teman dalam diskusi pada model pembelajaran koopertif tipe numbered heads together pada penelitian ini berarti siswa telah melaksanakan teori belajar konstruktivisme sosial dengan baik.

Hubungan hasil penelitian dengan model pembelajaran kooperatif. Beberapa hal yang tampak pada hasil penelitian ini berhubungan dengan kelebihan model pembelajaran kooperatif adalah sebagai berikut : (1) Dapat menambah motivasi dan percaya diri, hal ini terlihat pada saat siswa mendapat nomor undian untuk melaksanakan presentasi, dengan rasa percaya diri yang tinggi siswa bersangkutan maju untuk mempresentasikan hasil diskusi kelompok di depan kelas. Siswa yang maju mampu mengkomunikasikan hasil belajar kelompok mereka di depan teman-temannya dan hal ini dapat menambah motivasi dan rasa percaya diri siswa. (2) Dapat mengurangi rasa apatis, hal ini terlihat pada saat aktifnya setiap siswa dalam diskusi kelompok. Setiap individu merasa bertanggung jawab untuk menemukan jawaban yang benar dari soal yang didiskusikan. (3) Dapat meningkatkan kemajuan belajar, hal ini terlihat dari meningkatnya aktivitas belajar siswa. (4) Menambah rasa senang berada di sekolah serta menyenangi teman-teman sekelasnya, hal ini terlihat saat pembagian kelompok belajar, tidak ada siswa yang kelihatan sedih dan keberatan untuk menjadi anggota kelompok tertentu. Mereka dengan senang hati menerima teman-teman dalam 
kelompoknya untuk duduk berdiskusi bersama-sama.

Hubungan hasil penelitian dengan tipe numbered heads together. Beberapa hal yang muncul pada hasil penelitian ini berhubungan dengan keunggulan tipe numbered heads together adalah sebagai berikut : (1) Setiap siswa menjadi siap, hal ini terlihat pada saat pencabutan nomor undian untuk presentasi jawaban diskusi di depan kelas, mereka dengan semangat maju ke depan kelas untuk mempresentasikan hasil diskusi kelompok dan mereka dapat menjawab hasil diskusi dengan benar. (2) Dapat melakukan diskusi dengan sungguh-sungguh, hal ini terlihat pada saat pelaksanaan diskusi kelompok tidak ada siswa yang meninggalkan kelompoknya, mereka tidak membuat kegaduhan, berdiskusi dengan tertib. (3) Siswa yang pandai dapat mengajari siswa yang kurang pandai hal ini terlihat pada pelaksanaan diskusi dan jawaban hasil diskusi kelompok. Beberapa siswa yang mempresentasikan hasil diskusi kelompok adalah siswa yang kurang pandai dan belum pernah tampil di depan teman-temannya untuk menjawab soal kimia, tetapi begitu mendapat kesempatan untuk menjawab soal diskusi mereka dapat menjawab dengan baik dan benar.

Hasil pengamatan peneliti selama penelitian. Beberapa hasil pengamatan peneliti pada saat pelaksanaan tindakan dari siklus I sampai siklus III adalah sebagai berikut : (1) Diskusi kelompok berjalan dengan baik, dimana siswa aktif berdiskusi dalam kelompoknya. Hal ini terlihat ketika mereka membagi tugas kepada masingmasing anggota, ada yang mencari jawaban soal, ada yang membacakan jawaban dan didengarkan secara bersama, apabila jawaban sudah benar lalu ditugaskan kepada salah satu siswa untuk mencatat setiap jawaban tersebut. Jadi, ada partisispasi aktif tiap anggota, ada tanggung jawab bersama. (2) Memerlukan banyak waktu untuk mempresentasikan hasil diskusi. Pelaksanaan presentasi siklus I tidak sesuai skenario yang dialokasikan dalam RPP. Pada siklus II ada perbaikan tetapi masih memerlukan banyak waktu dalam pelaksanaannya. Penyebab molornya pelaksanaan presentasi tindakan siklus I adalah : (1) lamanya pengundian nomor siswa yang melakukan presentasi ; (2) belum terbiasanya siswa dengan model pembelajaran kooperatif tipe numbered heads together; (3) siswa terlalu lama berfikir untuk menjawab pertanyaan karena harus membuka LKS atau buku terlebih dahulu untuk mencari jawaban pertanyaan. Jadi, model pembelajaran koopetaif tipe numbered heads together sulit dilaksanakan di sekolah karena memerlukan waktu panjang dalam pelaksanaannya.

\section{Simpulan dan Saran}

Berdasarkan hasil analisis data dapat disimpulkan bahwa penerapan model pembelajaran kooperatif tipe numbered heads together dapat meningkatkan aktivitas belajar pada materi polimer di kelas XII IPA SMA Negeri 2 Pontianak. Pada siklus I siswa yang aktif sebanyak 9 siswa $(29,03 \%)$ dari 31 siswa, pada siklus II siswa yang aktif sebanyak 14 siswa $(43,75 \%)$ dari 32 siswa dan pada siklus III siswa yang aktif sebanyak 23 siswa $(71,88 \%)$ dari 32 siswa. 
Penerapan model pembelajaran kooperatif tipe numbered heads together pada materi polimer dapat menyenangkan semua siswa, meningkatkan kerjasama antarsiswa, membantu memecahkan kesulitan belajar, meningkatkan kepercayaan diri dalam memecahkan masalah kimia dan dapat meningkatkan keberanian untuk mempresentasikan jawaban dihadapan teman-teman di depan kelas.

Disarankan kepada guru untuk merancang waktu sebaik-baiknya sehingga pelaksanaan model pembelajaran kooperatif tipe numbered heads together sesuai dengan waktu yang telah dialokasikan dalam RPP.

\section{Daftar Pustaka}

Budimansyah Dasim, Suparlan dan Meirawan Danny, (2010). Pembelajaran Aktif, Kreatif, Efektif, dan Menyenangkan. Bandung : PT Genesindo.

Hermawan, Hendy. (2006). Modelmodel Pembelajaran Inovatif. Bandung : CV Citra Praya.
Mulyasa, E. (2009). Praktik Penelitian Tindakan Kelas. Bandung : PT Remaja Rosdakarya.

Rohman, Arif. (2011). Memahami Pendidikan dan Ilmu Pendidikan. Yogyakarta : LaksBang Mediatama.

Suparno, Paul. (2008). Riset Tindakan untuk Pendidik. Jakarta : PT Grasindo.

Suprijono, Agus. (2013). Cooperatif Learning Teori dan Aplikasi PAIKEM. Yogyakarta : Pustaka Pelajar.

Sutresna, Nana. (2007). Cerdas Belajar Kimia untuk Kelas XII SMA/MA ProgramIPA. Bandung : Grafindo Media Pratama.

Wena, Made. (2009). Strategi Pembelajaran Inovatif Kontemporer. Jakarta : PT BumiAksara. 